Journal of Applied Pharmaceutical Science Vol. 4 (10), pp. 047-050, October, 2014

Available online at http://www.japsonline.com

DOI: $10.7324 / \mathrm{JAPS} .2014 .401009$

ISSN 2231-3354 (cc)) BY-NC-SA

\title{
Antimicrobial and Cytotoxic Activities of Endophytic Fungi Isolated from Artemisia annua L
}

\author{
Puji Astuti ${ }^{1}$, Wahyono ${ }^{1}$, Titik Nuryastuti ${ }^{2}$, Indah Purwantini ${ }^{1}$, Purwanto $^{1}$ \\ Pharmaceutical Biology Department, Faculty of Pharmacy, Universitas Gadjah Mada, Yogyakarta, Indonesia. \\ Microbiology Laboratory, Faculty of Medicine, Universitas Gadjah Mada, Yogyakarta, Indonesia.
}

\begin{tabular}{l} 
ARTICLE INFO \\
\hline Article history: \\
Received on: $12 / 08 / 2014$ \\
Revised on: $28 / 08 / 2014$ \\
Accepted on: $21 / 09 / 2014$ \\
Available online: $30 / 10 / 2014$ \\
\hline Key words: \\
antimicrobial, cytotoxic, \\
fungal endophytes, A. аппиа \\
L
\end{tabular}

\begin{abstract}
This study was aimed to investigate antimicrobial and cytotoxic effects of endophytic fungi isolated from A. апnиа L. The ethyl acetate extracts were obtained by liquid-liquid partition of fermentation broth of endophytes followed by evaporation. Antimicrobial assay was determined by disc diffusion method. Cytotoxicty assay was conducted against T47D, WiDr and Vero using MTT assay. Data generated were used to determine $\mathrm{IC}_{50}$. While DP2 extract did not show any inhibition against all tested bacteria, DP6 extract at $200 \mu \mathrm{g}$ inhibited the growth of $B$. subtilis, $P$. aeruginosa and $S$. thypi with the highest inhibition against $B$. subtilis. Similarly, E2 extract inhibited the growth of B. subtilis, E. coli and $S$. thypi, with the highest inhibition against $B$. subtilis. The three extracts (DP2, DP6 and E2) were found to be cytotoxic against T47D and WiDr with E2 extract to be the most cytotoxic. These compounds were more selective against T47D cell line with $\mathrm{IC}_{50}$ of 91.7, 74.8 and 12.0 $\mu \mathrm{g} / \mathrm{mL}$, respectively. The $\mathrm{IC}_{50}$ against Vero cell line are $444.4,140.3$ and $87.7 \mu \mathrm{g} / \mathrm{mL}$, respectively.
\end{abstract}

\section{INTRODUCTION}

Natural products are sources of bioactive compounds potential to be developed as pharmaceutical agents. Endophytic microbes are one group of microorganisms capable of producing active metabolites which then attract the attention of scientists since the finding of paclitaxel which can be generated by a fungus colonizes Himalayan yew tree, Pestalotiopsis microspore(Tan and Zou, 2001). Endophytic microbes reside in living plant tissues without causing damage to the host. They colonize in plant tissues such as in leave, stem, root and seed and have been recognized to produce bioactive metabolites potentially having medicinal values such as alkaloids, terpenoids, polyketides, phenylpropanoids, aliphatic compounds, and peptides (Pinheiro et al., 2013; Mousa et al., 2013; Zheng et al., 2013; de Souza et al., 2011). Artemisia annua L., is aplant which grow on tropical countries and known to produce artemisinin with a range of concentration of 0.01-1.1\% (Alam et al., 2010). Artemisinin is a famous drug against malaria, one of most deadly infections in tropical countries. This compound and its derivates have been reported to have such

\footnotetext{
* Corresponding Author

Puji Astuti, Pharmaceutical Biology Department, Faculty of Pharmacy, Universitas Gadjah Mada, Yogyakarta, Indonesia

Email :puji_astuti@ugm.ac.id
}

anticancer activities with various mechanism of actions as cell cycle arrest, apoptosis, inhibition of angiogenesis, inhibition of Wnt $/ \beta$ catenin pathway and disruption of cell migration (Fireston et al., 2009; Krishna et al., 2008; Li, 2007, Zhou, 2007). However, the low level of production of artemisinins from the $A$ annua, limits its exploration directly from the plantsfor commercialization. Other methods are developed to find bioactive compounds from A. апnиa. Drimartol A, a sesquiterpenecoumarin has been isolated from $A$. annuahairy root culture and this compound was reported to have anticancer activity (Zhai and Zhong, 2010). Endophytes of A. аnnua are also a source of microorganisms potential to be developed for production of bioactive compounds. Twenty one of 39 endophytes of A.annua, have been isolated and reported to have antifungal activities (Liu et al., 2001). Artemisinin, the antimalarial drug has been reported to be produced by endophytic actinobaceria Pseudonocardia $s p$ (Li et al., 2012). Many studies reported the ability of antimicrobial compounds to function as anticancer agents and anthracyclines are an example of a well-known antibiotics used as anticancerdrugs (Mordente et al., 2012). In this study we investigated the antimicrobial and cytotoxic activities of compounds produced by endophytes of A. Annua collected from National Centre for Research and Development of Medicinal Plants and Traditional Medicine, Tawangmangu, Indonesia. 


\section{MATERIALS AND METHODS}

\section{Source of endophytic fungi}

Plant materials were collected from National Centre for Research and Development of Medicinal Plants and Traditional Medicine, Tawangmangu, Indonesia. The parts of plant were collected and stored at $4^{\circ} \mathrm{C}$ until used. The living plant was grown on green house, the species was identified by Faculty of Biology Universitas Gadjah Mada Indonesia and the specimen was stored in the Faculty of Pharmacy Universitas Gadjah Mada Indonesia.

\section{Isolation of endophytic fungi.}

Isolation of endophytic fungi from $A$. апnиa $\mathrm{L}$, was carried out by sterilizing the surface of healthy plant tissues in running tap water for 10 minutes. After washing with $70 \%$ ethyl alcohol for $1 \mathrm{~min}$, the samples were soaked in 5\% sodium hypochlorite for $3 \mathrm{~min}$, immersed with $70 \%$ ethyl alcohol for $30 \mathrm{~s}$ and followed by thrice rinses with sterile distilled water.

The surfaces sterilized samples were cut aseptically into small pieces of $1 \mathrm{~cm}$ long segments using a sterile blade and placed on the plates with PDA medium supplemented with streptomycin $(30 \mu \mathrm{g} / \mathrm{mL})$ for incubation at $25{ }^{\circ} \mathrm{C}$. Each fungal colonies growing in plant tissues were transferred into new PDA plates without antibiotics until cultures were obtained for fermentation and collection. The culture collections were deposited in Pharmaceutical Biology Department, Faculty of Pharmacy UniversitasGadjahMada, Indonesia.

\section{Semipolar extraction of fermentation cultures}

The pure fungal endophytic cultures were fermented in $200 \mathrm{~mL}$ culture flasks containing potato dextrose broth for 10 days at $25{ }^{\circ} \mathrm{C}$ on a shaker at $160 \mathrm{rpm}$. Following fermentation, the culture broth were filtered with Whatman filter paper and centrifuged at $4000 \mathrm{rpm}$ for $5 \mathrm{~min}$. Liquid supernatant was extracted with an equal volume of ethyl acetate thrice and the ethyl acetate fractions were evaporated to yield an ethyl acetate extract. The extracts were dissolved in ethanol for antimicrobial and cytotoxicity testing.

\section{Antimicrobial activity}

Screening for antimicrobial activities was carried out by using disc diffusion method (Momin et al., 2014) against four pathogenic bacterial strains (B. subtilis, E.coli, P. aeruginosa, S. typhi) at dose of extracts of $200 \mu \mathrm{g} / \mathrm{disc}$. The test microorganisms were inoculated in $10 \mathrm{~mL}$ sterile nutrient agar and transferred into petri dishes in aseptic condition to give a solid plate. The extracts were applied into the disc and deposited on the surface of agar plates. The plates were incubated overnight atat $37^{\circ} \mathrm{C}$. Clear zones of inhibition surrounding the disks were measured at the end of incubation and the diameters were expressed in $\mathrm{mm}$.

\section{Cytotoxic activity}

Three cell lines used in this study were T47D (Human ductal breast epithelial tumor cell line), WiDr (human colon carcinoma cell line) and Vero (African green monkey kidney epithelial cell line). The cells were cultured in RPMI 1640 supplemented with $10 \%$ heat inactivated fetal bovine serum (FBS) and $1 \%$ penicillin/streptomycin and maintained at $37^{\circ} \mathrm{C}$ in an atmosphere of $5 \% \mathrm{CO} 2$. Cytotoxicity assay conducted by $3-(4,5-$ dimethylthiazol-2-yl)-2,5-diphenyltetrazoliumbromide (MTT) assay adapted from Mosmann (1983) with minor modification. Control and treated cells inoculated at 96 well plate were incubated for $24 \mathrm{~h}$ and read using a spectrophotometer at $595 \mathrm{~nm}$. The concentration of extracts required to kill $50 \%$ of cell population $\left(\mathrm{IC}_{50}\right.$ ) was determined from data generated by plotting a dose-response curve.

\section{RESULTS AND DISCUSSION}

\section{Endophytic Fungi and Its Metabolite Characterization}

Total of seven distinct fungal isolates were obtained from the plant collected from National Centre for Research and Development of Medicinal Plants and Traditional Medicine, Tawangmangu, Indonesia. Based on initial screening, three of them (namely DP2, DP6 and E2) produced compounds having antibacterial activities. The chromatographic profiles of the extract under UV 366 and UV 254 indicated the presence of various compounds within the extracts (Figure 1). There was one major compound within DP6 with hRf of 0.40 which absorb $254 \mathrm{~nm}$ UV light to give dark spots against green fluorescence.
A

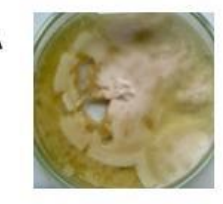

B

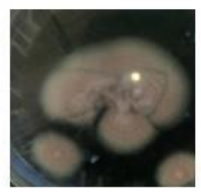

C

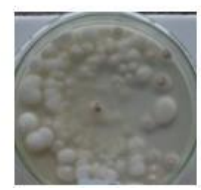

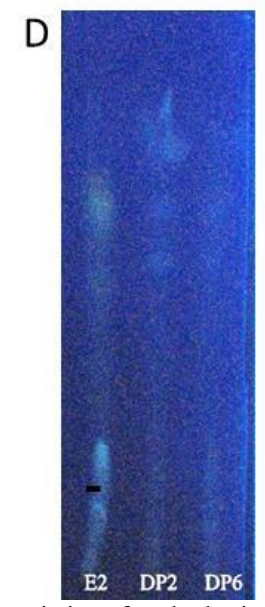

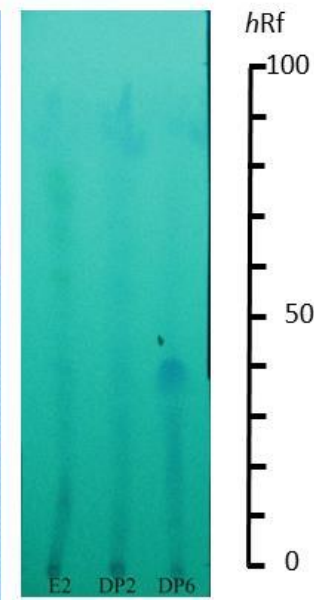

Fig. 1: Morphology characteristics of endophytic fungi isolated from A. аnnua and TLC profiles of its ethyl acetate extracts. Endophytic fungi DP2 (A), DP6 (B) and E2 (C) grown on PDA; its TLC profiles (stationary phase: silica gel $\mathrm{F}_{254}$; mobile phase: chloroform: ethyl acetate: 1:2) detected using $\mathrm{UV}_{366}$ and $\mathrm{UV}_{254}$ (D).

\section{Antimicrobial activities}

Ethyl acetate extracts obtained from the fermentation broth of the three fungi were screened for antimicrobial activities against B. subtilis, E.coli, P. aeruginosa, S. typhi(Table 1).Two extracts at given concentration $(200 \mu \mathrm{g})$ showed any inhibition against testing microorganisms. DP6 and E2 extracts showed greater activities against $B$. subtilis. These extracts also inhibited the growth of $S$. thypi, although the inhibition zone is less than that 
against B. subtilis. In addition, DP6 inhibited the growth of $P$. aeruginosa, whilst E2 against E. coli. DP2 extract at dose of 200 $\mu \mathrm{g}$ did not show any inhibition against four testing microorganisms.

Table 1: Antimicrobial activity of extracts against B. subtilis, E. coli, P. aeruginosa, $S$. typhias determined by disc diffusion test.

\begin{tabular}{cccccc}
\hline \multirow{2}{*}{ No } & \begin{tabular}{c} 
Extracts \\
\cline { 3 - 6 }
\end{tabular} & \multicolumn{4}{c}{ Inhibition zones $(\mathbf{m m})$} \\
\cline { 3 - 6 } & $\mathbf{2 0 0}$ subtilis & E. coli & P. aeruginosa & S. typhi \\
\hline 1 & DP2 & - & - & - & - \\
2 & DP6 & 24 & - & 7.08 & 6.87 \\
3 & E2 & 20.85 & 9.50 & - & 10.35 \\
\hline
\end{tabular}

\section{Cytotoxic activity}

An attempt to examine the bioactivity of these three compounds against cancer cell lines was conducted. Cytotoxicity of the extracts against T47D and WiDr celllines is shown in Table 2. At dose of $250 \mu \mathrm{g} / \mathrm{mL}$ addition of DP6 extract showed more death than DP2. In addition less dose were needed to kill T47D cells upon administration of E2 extract (Figure 2). Generally, the extracts were found to be more effective against T47D than the WiDr cell line. IC50s of these compounds $<100 \mu \mathrm{g} / \mathrm{mL}$ against T47D and one of them (E2) had IC50 of $<20 \mu \mathrm{g} / \mathrm{mL}$. These compounds were found to be less cytotoxic against WiDr, with IC50 values of DP2, DP6 and E2 of 332.9, 128.9 and $79.8 \mu \mathrm{g} / \mathrm{ml}$, respectively.

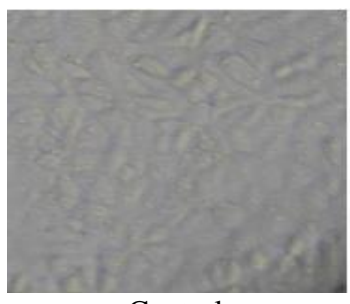

Control

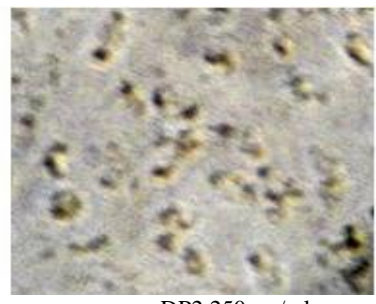

DP2 $250 \mu \mathrm{g} / \mathrm{ml}$
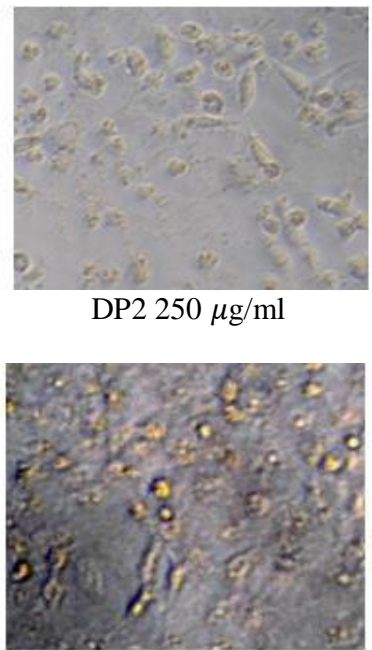

E2 $62.5 \mu \mathrm{g} / \mathrm{ml}$
DP2 $250 \mu \mathrm{g} / \mathrm{ml}$

Fig. 2: Morphologic profiles of T47D cells treated with ethyl acetate extracts of DP2, DP6 and E2 at given concentration.

Table 2: IC50 of endophytic extracts against T47D, WiDr and Vero cell lines $(\mathrm{n}=4)$

\begin{tabular}{cccc}
\hline \multirow{2}{*}{ Extracts } & \multicolumn{3}{c}{$\mathbf{I C}_{\mathbf{5 0}}(\boldsymbol{\mu g} / \mathbf{m L})$} \\
\cline { 2 - 4 } & T47D & WiDr & Vero \\
\hline DP2 & 91.7 & 332.9 & 444.4 \\
DP6 & 74.8 & 128.9 & 140.3 \\
E2 & 12.0 & 79.8 & 87.7 \\
\hline
\end{tabular}

To examine the selectivity of these compounds, cytotoxicy testing was also conducted against normal Vero cell line. We found that DP2, DP6 and E2 had IC50 of 444.4, 140.3, $87.7 \mu \mathrm{g} / \mathrm{ml}$, respectively. These results showed that the extracts were more selective against T47D than WiDr. A. annua is a subtropical plant which is known to produce well known anti-malarial compound artemisinin. Beside its function as antimalarial drug, artemisinin and its derivatives have been reported to affect cancer cells with various mechanisms such as cell cycle arrest, apoptosis, disruption of cell migration as well as angiogenesis inhibition (Firestone andSundar, 2009; Krishna et al., 2008). On the otherhand, endophytic fungi has been known to produce novel secondary metabolites with some of them possess bioactivitiesand medical values (Ally et al., 2010; Katoch et al., 2014).Li et al (2012) reported the production of artemisinin by endophytic actinobaceria Pseudonocardia sp.

In agreement with the fact that fungal endophytesare potential sources of bioactive compounds, ethyl acetate extracts obtained from fermentation broth of endophytic fungi isolated fromA. annuaalso showed bioactivities. Based on initial screening using hole plate assay, three from seven fungi isolated from A. апnиа collected from National Centre for Research and Development of Medicinal Plants and Traditional Medicine, Tawangmangu, Indonesia showed inhibition zones against testing microorganism. In this study the endophytes present in this plant may not all grow and have been isolated since some may need special conditions which were different with those in laboratory. The three endophytes then were further characterized for their potencies.

In this study we found that bioactivities of these three endophytes were not identical although they were isolated from the same species and the same locations. Only two of them showed inhibition against testing microorganisms with different level of inhibitions. Similarly, the bioactive abilities of endophytic fungi against cancer cell lines were not identical with one to be more cytotoxic than others; one to be more selective than others. These might be explained by the fact that the mixture compounds produced by these endophytes are different as characterized by TLC profiles.

Strongest inhibitions were clear against $B$. subtilis, whilst in general they were found to be more cytotoxic and selective against T47D.We found that one of the extract (E2) had IC50 value of less than $20 \mu \mathrm{g} / \mathrm{ml}$, the value within the standard point set up by National Cancer Institute for cytotoxicity screening of crude plant extracts (Lee et al., 2005).

Many studies reported the ability of antimicrobial compounds to function as anticancer agents and anthracyclines are an example of a well-known antibiotics used as anticancer drugs (Mordente et al., 2012).These data demonstrated that the extracts were potential to be developed as anti-cancer drugs and needs further investigation.

\section{CONCLUSION}

This finding suggested the presence of bioactive compounds within ethyl acetate extracts of endophytic fungi isolated from A. апnua which are potential for development as pharmaceutical agent. 


\section{ACKNOWLEDGEMENT}

This research was supported by Multidiscipline Project of Universitas Gadjah Mada under Indonesian Ministry of Education and Culture Grant (Grant no: LPPM-UGM/683/BID.I/ 2012).

\section{REFERENCE}

Alam P, Kiran U, Ahmad MM, Kamaluddin, Khan MA, Jhanwar S, Abdin MZ.Isolation, characterization and structural features of amorpha-4, 11-diene synthase $\left(\mathrm{ADS}_{3963}\right)$ from Artemisia annиaL. Bioinformation,2010;4(9): 421-429.

Aly AH, Debbab A, Kjer J,Proksch P. Fungal endophytes from higher plants: a prolific source of phytochemicals and other bioactive natural products. Fungal Divers,2010; 41:1-16.

DeSouza JJ, Vieira IJ, Rodrigues-Filho E, BrazFilho R.Terpenoids from endophytic fungi.Molecules,2011; 16(12):1060418.

Firestone GL, Sundar SN. Anticancer activities of artemisinin and its bioactive derivatives, Expert Rev Mol Med, 2009; $11: \mathrm{e} 32$

Katoch M, Singh G, Sharma S, Gupta N, Sangwan PL, Saxena A. Cytotoxic and antimicrobial activities of endophytic fungi isolated from Bacopamonnieri (L.) Pennell (Scrophulariaceae), BMC Complement Altern Med, 2014; 14:52.

Krishna S, Bustamante L, Haynes RK, Staines HM. Artemisinins: their growing importance in medicine. Trends Pharmacol Sci, 2008; 29(10): 520-527.

Kusari S, Zühlke S, Spiteller M. An endophytic fungus from Camptotheca acuminata that produces camptothecin and analogues. J Nat Prod,2009: 72(1):2-7.

Lee CC, and Houghton P. Cytotoxicity of plants from Malaysia and Thailand used traditionally to treat cancer. J Ethnopharmacol, 2005: 100:237-243.

Li LN. Artesunate attenuates the growth of human colorectal carcinoma and inhibits hyperactive Wnt/ $\beta$-catenin pathway. Int J Cancer, 2007; 121:1360-1365.

Li J, Zhao GZ, Varma A, Qin S, Xiong Z, Huang HY, Zhu WY, Zhao LX, Xu LH, Zhang S,Li WJ. An endophyticPseudonocardia species induces the production of artemisinin in Artemisia annиa. PLoS One, 2012; 7(12).

Liu CH, Zou WX, Lu H, Tan RX. Antifungal activity of Artemisia аппиа endophyte cultures against phyto-pathogenic fungi. J Biotechnol, 2001; 88(3):277-282.

Momin MA, Bellah SF, Rahman SM, Rahman AA, Murshid GM, Emran TB. Phytopharmacological evaluation of ethanol extract of Sidacordifolia L. roots. Asian Pac J Trop Biomed, 2014;4(1):18-24.
Mordente A, Meucci E, Silvestrini A, Martorana GE, Giardina B. Anthracyclines and mitochondria. Adv Exp Med Biol, 2012; 942:385419.

Mosmann F. Rapid calorimetric assay for cellular growth an survival: application to proliferation and cytotoxicity assay. J Immunol Methods, 1983; 65:55-63.

MousaWK, and Raizada MN. The diversity of anti-microbial secondary metabolites produced by fungal endophytes: an interdisciplinary perspective. Front Microbiol, 2013; 4:65.

Pinheiro EA, Carvalho JM, dos Santos DC, Feitosa Ade O, Marinho PS, Guilhon GM, de Souza AD, da Silva FM, Marinho AM Antibacterial activity of alkaloids produced by endophytic fungus Aspergillus sp. EJC08 isolated from medical plant Bauhinia guianensis. Nat Prod Res, 2013; 27(18):1633-8.

Puri SC, NazirA, Chawla R, Arora R, Riyaz-Ul-Hasan S, Amna T, Ahmed B, Verma V, Singh S, Sagar R., Sharma A, Kumar R, Sharma RK, Qazi GN. The endophytic fungus Trameteshirsuta as a novel alternative source of podophyllotoxin and related aryl tetralinlignans.J Biotechnol, 2006; 122(4):494-510.

Strobel G and Daisy B. Bioprospecting for microbial endophytes and their natural products. Microbiol Mol Biol Rev, 2003; 67(4):491-502.

Strobel GA. Endophytes as sources of bioactive products. Microbes Infect, 2003; 5(6):535-44.

Tan RX and Zou WX. Endophytes: a rich source of functional metabolites. Nat Prod Rep, 2001; 18(4):448-59.

Zhai DD and Zhong JJ. Simultaneous analysis of three bioactive compounds in Artemisia аппиа hairy root cultures by reversedphase high-performance liquid chromatography-diode array detector. Phytochem Anal, 2010; 21(6):524-530.

Zheng CJ, Xu LL, Li YY, Han T, Zhang QY, Ming QL, Rahman K, Qin LP. Cytotoxic metabolites from the cultures of endophyticfungi from Panax ginseng. Appl Microbiol Biotechnol, 2013; 97(17):7617-25.

Zhou HJ. Artesunate inhibits angiogenesis and downregulates vascular endothelial growth factor expression in chronic myeloid leukemia K562 cells. Vascul Pharmacol, 2007;47:131-138.

\section{How to cite this article:}

Puji Astuti, Wahyono Wahyono, Titik Nuryastuti, Indah Purwantini, Purwanto Purwanto. Antimicrobial and Cytotoxic Activities of Endophytic Fungi Isolated from Artemisia annua L. J App Pharm Sci, 2014; 4 (10): 047-050. 